\title{
Effects of Spontaneous Collaborative Group Approach and REFLECT on Pupils' Achievement in HIV/AIDS Education
}

\author{
Oludola Sarah Sopekan* \\ Department of Arts and Social Sciences Education, University of Lagos, Lagos, Nigeria \\ *Corresponding author: sopekansarah@yahoo.co.uk
}

Received October 08, 2013; Revised December 19, 2013; Accepted January 20, 2014

\begin{abstract}
Primary School pupils constitute a sub-group of young people world-wide exposed to the risk of HIV infection despite various awareness programmes to combat HIV/AIDS prevalence as stated by Goal six of the millennium development goals (MDGs), about its prevalence. Increase in death rates showed that there was low correlation between pupils' achievement and HIV/AIDS education. However, there were few studies conducted on HIV/AIDS education in Nigerian primary schools and these studies had failed to suggest specific teaching methods for teachers to use. This study investigated the effects of Spontaneous Collaborative Group Approach and Regenerated Freiran Literacy through Empowering Community Techniques (REFLECTS) on pupils' achievement in HIV/AIDS education using gender as a moderator variable. The study adopted a pre-test, post-test, control group, quasi experimental design with a sample of 399 primary five and six pupils from nine public primary schools in Ogun State, Nigeria. The result showed a significant main effect of treatment on pupils' achievement in HIV/AIDS education in which pupils exposed to the REFLECT and Spontaneous Collaborative Group Approach performed significantly better than their counterparts exposed to the conventional teaching method. In addition, gender had no significant main effect on pupils' achievement in HIV/AIDS education. Based on the findings, it was recommended that primary school teachers teaching the core-subjects in which HIV/AIDS education had been incorporated should use participatory teaching strategies such as REFLECT and Spontaneous Collaborative Group Approach in their classes.
\end{abstract}

Keywords: primary school pupils, HIV/ADS, achievement, spontaneous Collaborative Group Approach, REFLECTS, millennium development goals

Cite This Article: Oludola Sarah Sopekan, "Effects of Spontaneous Collaborative Group Approach and REFLECT on Pupils' Achievement in HIV/AIDS Education.” American Journal of Educational Research, vol. 2, no. 1 (2014): 29-34. doi: 10.12691/education-2-1-6.

\section{Introduction}

The emergence of the HIV/AIDS epidemic has been a major cause of concern worldwide, especially in the developing countries. Since the epidemic began, it is estimated that more than 25 million people have died. Africa has 12 million AIDS orphans and at the end of 2006, women accounted for 50 percent of all adults living with HIV worldwide, 61 percent in Sub-Saharan Africa in which Nigeria is one (UNAIDS/WHO, 2007). Similarly, there has been an alarming increase in the number of AIDS orphans in Nigeria. Findings show that over one million Nigerian children have been made orphans as a result of HIV/AIDS related deaths (http://www/vanguardngr.com/2013/08/hivaids-problemsof-orphans-vulnerable-children-in Nigeria). HIV/AIDS has been a subject of curriculum renewal in Nigeria as it is considered one of the leading emergent issues (Awofala \& Sopekan, 2013; Awofala, 2012) that need urgent attention in the Nigerian education in order to reduce death and promote longevity. In Ogun State, the South-West zone of Nigeria, it was estimated that out of a population of $3,308,128$, the number of people infected with HIV by January 2008 was 33,082 (Abiodun, Dairo, \& Ojetunde, 2007). Studies also suggested that the impact of orphanhood on a child's education was closely interlinked with other factors such as poverty (Adimora, 2006, Cohen 2007). Figures released in 2010 revealed the gap between school attendance by orphans and non-orphans in most sub-Saharan Africa countries due to poverty. This made millions of children to be deprived of sound health and never experienced the joy of childhood. Consequently, the Federal Government of Nigeria through its public primary schools can play a vital role in improving their prospects and securing their future through quality education delivery. Quality education through appropriate teaching methods and strategies can lift children out of poverty, by decreasing the risk of infection, increase their self-esteem, expose them to better job prospect, and economic independence. Apart from providing emotional support, 
public primary school teachers will be well equipped with participatory teaching methods that will increase their students' knowledge acquisition. Moreover, in a number of studies conducted in Nigeria, poor achievement in HIV/AIDS education was linked to teachers' inability to use modern teaching methods most especially at the primary level of education. While sex is not the only transmission route to HIV infection, ignorance about the disease will condemn many young people to an early grave based on their low achievement in HIV/AIDS education. There is a growing concern that unless some urgent actions are taken to curtail or stop the spread of HIV/AIDS and care for people living with HIV/AIDS, the goals of Universal Basic Education (UBE) and the Millennium Development Goals (MDGs) would not be realized. World Bank (2002) emphasized participatory and other innovative teaching methods in HIV/AIDS education.

Kolawole (2007) also emphasized that the best way to reduce the impact of HIV/AIDS in Nigeria, Sub-Saharan African, and the world at large is to reach the grassroots through participatory approaches such as radio jingles, drama, short stories and proverbs. The present study investigated the effects of Spontaneous Collaborative Group Approach and REFLECT on primary school pupils' achievement in HIV/AIDS education. Reflect is an innovative approach to learning and social change that combines the theories of Paulo Freire with participatory methodologies developed for Participatory Rural Appraisal (PRA). Freire was a Brazilian educator who radicalised a generation of literacy workers in the $1960 \mathrm{~s}$ and 1970 s by linking literacy to social change. He promoted 'conscientisation'-the process of learning to perceive social, political and economic contradictions and take action by deconstructing contradictions and negotiating more equal conditions. PRA is used in the development field to engage with communities in a participatory way and learn from them in terms of their realities (South Africa Reflect Network, 2010). The approach requires a transformation of traditional classroom roles, placing learners at the centre of their own learning process. The teacher becomes facilitator, their role transformed from one of directing or transferring knowledge to one of facilitating, sharing, enabling and catalysing, as well as learning and reflecting themselves. The participants therefore set their own agenda, identify their own issues, prepare their own learning materials and act on their analysis (South Africa Reflect Network, 2010).

REFLECT enabled the learners to suggest and choose their own learning materials. The teacher served as a guardian and does not dominate the class. A range of other participatory approaches can also be interwoven with REFLECT including the use of play, drama, songs, dance, story-telling, radio, jingles, local materials, games or proverbs. Steps involved in REFLECT are:

i. Identification of Issue/Problem: that is sickness in the family.

ii. Analysis and Discussion: Learners figure out what type of sickness, what are the symptoms, and what can be used in terms of medication.

iii. Planning and Action: Have 1 to 3 plans of action after executing the first and there is no solution, try the second, before the second is exhausted, there is going to be a solution, if not use the third plan. iv. Linking Participatory Learning: Sensitize learners about their problems; let them voice them out and then proffer solutions.

v. Supplementary Learning Materials: Use of other learning materials such as games, drama, playlets, songs or films.

vi. Additional Learning: Give assignments, materials for further reading, references or ask their own opinion about the topic.

Moreover, Spontaneous Collaborative Group Approach is a partial-group work in which learners through active involvement learn many useful concepts for future use. This is a strategy of collaboration where pupils who were divided into groups are expected to work individually on the same problem. The pupils join and help one another. But the teacher joins them to raise questions, correct their mistakes and help them to settle conflicts. This model might not look like a collaborative group work because individuals are asked to provide individual products. But when pupils engage in a group work on the same problem, it is possible for them to contribute to one another's interest and understanding. This may influence their action, ideas and the quality of the end-product. In this approach, teacher also guides the group members on how to relate and whom to relate with. Pupils' score in the evaluation test will be regarded as individual score and not group or joint score.

The third method was the conventional method used for the control group. This is the teaching method in which the teacher dominates the class activities. Awofala, Arigbabu, and Awofala (2013) termed it the chalk-andtalk-method. The steps involved are:

i. The teacher introduces the lesson by asking questions on previous knowledge.

ii. Teacher explains the new topic.

iii. Teacher demonstrates the topic with relevant concrete object.

iv. Teacher writes notes for the pupils on the board.

v.Teacher asks question on the concept taught.

Apart from teaching approach used, gender had been found to have impact on learning outcome (Awofala, Arigbabu, \& Awofala, 2013, Awofala, 2011). Gender as one of the important variables in education in Nigeria had been frosted with inconclusive findings in relation to learning outcomes (Awofala, Arigbabu, \& Awofala, 2013; Awofala, 2007; Akinsola \& Awofala, 2009). Reported findings in gender had been mixed with some claiming that males showed more positive attitudes toward school subjects and performed better on achievement measure than their female counterparts (Awofala, 2011; Ogunneye, 2003; Akinsola \& Awofala, 2009) while others (Abakpa \& Iji, 2011; Ogunleye \& Babajide, 2011; Arigbabu \& Mji, 2004; Agommuoh \& Nzewi, 2003) observed no significant effect of gender on students' achievement in and attitudes toward school subject thus concluding that gender differences in attitudes and achievement/performance could be disappearing.

Therefore, the impact of gender on pupils' achievement in HIV/AIDS was also investigated. The study was being undertaken to add to the existing body of research on HIV/AIDS education in the Nigerian schools.

\subsection{Null Hypotheses}


$\mathbf{H o}_{1}$ : There is no significant main effect of treatment on pupils' achievement in HIV/AIDS education.

$\mathbf{H o}_{2}$ : There is no significant main effect of gender on pupils' achievement in HIV/AIDS education.

$\mathbf{H o}_{3}$ : There is no significant interaction effect of treatment and gender on pupils' achievement in HIV/AIDS education.

\subsection{Conceptual Framework}

The operational variables in this study include participatory approaches, gender, and achievement in HIV/AIDS education. It is hypothesized that sexuality is part of the child's development. Darwin (1964) stated that little boys and girls do no think about sex in the same way as adults do, sex related questions constantly asked are no more than the desire to understand the mechanics of how the child and his family came into existence. Freud referred to a drive or impulse as a stimulus within the peers which operates as a constant motivational force. Though each drive has its own form of psychic energy but he used libido for the sex drive. He further explains that the aim of the drive is to seek pleasure but this pleasure is not limited to genital satisfaction. Besides the genitals, the mouth, and anus are especially capable of producing sexual pleasure and these ones are collectively known as erogenous zones.

The adolescents direct their sexual energy toward another person instead of toward themselves. Education is expected to create the enabling and supportive environments to expose the risk associated with premarital sex including HIV/AIDS, the level of their susceptibility at puberty stage, and to make right sexual decisions which are the focus of this study.

\section{Method}

This study adopted a pretest posttest non-randomised control group quasi experimental design. It utilized the combination of cluster of areas and simple random sampling techniques. The researcher picked the sample from the cluster of HIV prevalence areas in Ogun State, Nigeria. These areas were selected because of the presence of truck drivers, foreign visitor and prostitutes who according to findings, could spread HIV infection. Nine schools and 399 pupils were used. The choice of primary five and six pupils was made because they had been exposed to marriage and pre-marital sex education in their social studies classes.

The selection of school was based on the following criteria:

i. Pupils' primary school with at least 15 years of existence.

ii. Co-educational school.

iii. Availability of experienced social studies teachers.

iv. Willingness of the required teachers to participate in the study.

v. Evidence of primary five and six pupils of the schools having been exposed to topics in Nigerian culture and pre-marital sex in their social studies classes.

One instrument was developed for the purpose of data collection: Pupils' HIV/AIDS education achievement test (PHAAT, $r=0.89$ ). The scores of the pupils in PHAAT were obtained before and after the treatment sessions in the two experimental groups and one control group. The teachers' instruction guides were constructed by the researcher for all the groups (Experimental \& control groups). These were to guide the teacher during their lessons. The last instrument, Assessment Sheet for Evaluation of Teacher Performance (ASETP) was used to evaluate the performance of the participating teacher based on the procedures for implementing participatory teaching strategies appropriate for their respective group.

The participating teachers and research assistants were trained for one week and the teachers who adhered most to the teaching approaches were finally selected. The pre-test was administered before teaching commenced and posttest was administered after the teaching. Treatment in each group lasted six weeks. Each lesson lasted 40 minutes duration per week with one lesson per week in each class. In line with national research guidelines, ethics approval was sought and given with parental consent and each young person's assent. Data collected were analyzed using analyses of covariance (ANCOVA) and multiple classification analysis (MCA) was used to determine the magnitude of the achievement of pupils in various groups. Scheffe's post-hoc was used where significant main effect was obtained. All the research questions were tested at $\mathrm{p}<$ 0.05 level of significance.

\section{Results}

$\mathbf{H o}_{1}$ : There is no significant main effect of treatment on pupils' achievement in HIV/AIDS education.

Table 1 revealed that there was a significant main effect of treatment on pupils' achievement in HIV/AIDS education $(\mathrm{F}(2,380)=5.936 ; \mathrm{p}<0.05)$. Therefore, $\mathrm{Ho}_{1}$ was rejected. Table 2 below showed the magnitude of performance across the groups.

Table 1. Summary of Analysis of Covariance on Pupils' Achievement in HIV/AIDS Education by Treatment and Gender

\begin{tabular}{|c|c|c|c|c|c|}
\hline Source & $\begin{array}{c}\text { Sum of } \\
\text { Squares }\end{array}$ & $\mathbf{d f}$ & $\begin{array}{c}\text { Mean } \\
\text { Square }\end{array}$ & $\mathbf{F}$ & Sig \\
\hline $\begin{array}{c}\text { Covariates Pre- } \\
\text { test }\end{array}$ & 16162.479 & 1 & 16162.479 & 2363.917 & 000 \\
\hline $\begin{array}{c}\text { Main Effect } \\
\text { (Combined) }\end{array}$ & 3243.63 & 5 & 648.726 & 94.882 & .000 \\
\hline Treatment & 81.178 & 2 & 40.589 & $5.936 *$ & .003 \\
\hline Gender & 11.121 & 1 & 11.121 & 1.627 & .203 \\
\hline $\begin{array}{c}\text { Treatment* } \\
\text { Gender }\end{array}$ & 1.265 & 2 & .632 & .092 & .912 \\
\hline Model & 19657.102 & 18 & 1092.016 & 159.124 & .000 \\
\hline Residual & 2598.121 & 380 & 6.837 & - & \\
\hline Total & 22255.223 & 398 & 55.910 & - & \\
\hline
\end{tabular}

*significant at $\mathrm{p}<.05$

Table 2 showed that pupils that were exposed to REFLECT performed better $(M=31.05)$, followed by those exposed to Spontaneous Collaborative Group Approach $(\mathrm{M}=30.38)$ while those exposed to conventional strategy performed least $(\mathrm{M}=28.27)$. 
Table 2. Multiple Classification Analysis (MCA) on Pupils' Achievement in HIV/AIDS Education

\begin{tabular}{|c|c|c|c|c|c|}
\hline Variable & $\mathbf{N}$ & $\begin{array}{c}\text { Unadjusted } \\
\text { Deviation }\end{array}$ & Eta & $\begin{array}{c}\text { Adjusted } \\
\text { Deviation }\end{array}$ & Beta \\
\hline $\begin{array}{c}\text { Treatment } \\
\text { Control }\end{array}$ & 133 & 2.16 & & -2.43 & \\
\hline $\begin{array}{c}\text { Spontaneous } \\
\text { Collaboration }\end{array}$ & 133 & 1.28 & .279 & -.32 & .63 \\
\hline Reflect & 133 & -3.89 & & .35 & \\
\hline $\begin{array}{l}\text { Gender } \\
\text { Male } \\
\text { Female }\end{array}$ & $\begin{array}{l}183 \\
216\end{array}$ & $\begin{array}{l}.53 \\
-.45\end{array}$ & .018 & $\begin{array}{l}.31 \\
-.26\end{array}$ & .023 \\
\hline $\begin{array}{l}\mathrm{R}=.934 \\
\mathrm{R}^{2}=.872\end{array}$ & & & & & \\
\hline
\end{tabular}

Table 3 below showed the source(s) of the significant difference among the groups. Table 3 showed that the significant difference revealed by Table 1 (ANCOVA) was as a result of the difference between Spontaneous Collaborative Group and Control group and REFLECTS and Control Group. But the two experimental treatment groups were not significantly different from each other.

Table 3. Scheffe's Port-Hoc Test

\begin{tabular}{|c|c|c|c|c|}
\hline Treatment & Mean & Control & $\begin{array}{c}\text { Spontaneous } \\
\text { Collaborative }\end{array}$ & REFLECT \\
\hline Control & 28.27 & & $*$ & $*$ \\
\hline $\begin{array}{c}\text { Spontaneous } \\
\text { Collaborative }\end{array}$ & 30.38 & $*$ & & \\
\hline REFLECT & 31.05 & $*$ & & \\
\hline
\end{tabular}

*pair significant at $\mathrm{p}<.05$

$\mathbf{H o}_{2:}$ There is no significant main effect of gender on pupils' achievement in HIV/AIDS education.

Table 1 revealed that there was no significant main effect of pupils' gender on their achievement in HIV/AIDS education $(\mathrm{F}(1,380)=1.627 ; \mathrm{p}>0.05)$. Therefore, $\mathrm{Ho}_{2}$ was not rejected.

$\mathbf{H o}_{3}$ : There is no significant interaction effect of treatment and gender on pupils' achievement in HIV/AIDS education.

Table 1 revealed that there was no significant interaction effect of treatment and pupils' gender on their achievement in HIV/AIDS education $(\mathrm{F}(2,380)=0.092$, $\mathrm{p}>$ 0.05). Therefore, $\mathrm{Ho}_{3}$ was not rejected.

\section{Discussion}

The first hypothesis which states that there is no significant main effect of treatment on pupils' achievement in HIV/AIDS education was rejected. It was observed that the effect of treatments on pupils' achievement in HIV/AIDS education was significant. One of the three teaching approaches used produced post test achievement score that was significantly better than the pre-test achievement score. On the other hand, REFLECT approach affected achievement most, followed by Spontaneous Collaborative Approach while the conventional approach had the least effect.

These findings supported the submission and findings of some other researchers that have used these approaches. REFLECT leads students to define the real life problem being presented, to discuss its causes, and to propose actions that can be taken to solve it (Freire 1969, 1993, Wallerstein, 1983). Smith (1989) also submitted that
Spontaneous Collaborative Group Approach facilitated active participation of learners in the learning process that the judgments or decision arrived at collectively was often superior to an individual one. This finding also supported earlier findings (Awofala, 2011; Akinsola \& Awofala, 2009; Akinsola \& Awofala, 2009; Awofala \& Nneji, 2012; Awofala, Fatade, \& Olaoluwa, 2012; Awofala, etal, 2013) which associated improved content learning to learnercentred teaching strategies.

The second hypothesis which states that there is no significant main effect of gender on pupils' achievement in HIV/AIDS education was not rejected. This finding supports the findings of some scholars like Ogunyemi (1994), and Akinbote et al (2001) that there existed no significant differences between male and female pupils in their learning outcomes in the various school subjects. The present study result of no gender differences in achievement in HIV/AIDS education supported the work of researchers who believed that gender stereotyping could be waning in the Nigerian educational system (Fatade, Nneji, Awofala, \& Awofala, 2012; Arigbabu \& Mji 2004). However, the result was at variance with the findings of some previous studies (Awofala, 2011 a; Awofala, 2007) that reported significant main effect of gender on students' performance in science and mathematics but agreed with some others (Awofala, 2011 b). This however, indicated that school children should be given equal opportunities irrespective of their gender and they should be taught learning approaches that are strong enough to eradicate or reduce the effect of gender on the learning outcomes to the barest minimum.

The third hypothesis which states that there is no significant interaction effect of treatment and gender on pupils' achievement in HIV/AIDS education was also not rejected. This finding did support the finding of some researchers (Awofala, etal., 2013; Awofala \& Nneji, 2012) who had found non-significant interaction effect of treatment and gender on students' learning outcomes. However, the finding disagreed with the results of other researchers who had found significant interaction effect of treatment and gender on students' learning outcomes (Awofala, Balogun, \& Olagunju, 2011). The nonsignificant interaction effect of gender and treatment recorded in this study showed that gender was not treatment sensitive on achievement in HIV/AIDS. This is another indicator that the total effects recorded in this research work could be attributed to the treatment only. Kerlinger (1973) submitted that in this type of research, the non-significant interaction effects of main and moderator variables implied that the main effect of the treatment can be reckoned with only.

\section{Conclusion and Recommendations}

The present study stands as part of multi-sectoral efforts of professionals including educators and researchers in Nigeria to mitigate the spread of HIV and AIDS epidemic. The more the number of participating pupils in the HIV/AIDS education through participatory teaching approach, the better they are reformed to take useful, life saving sexual decision. It was therefore recommended that:

i. Teachers need to be properly prepared for their role in carrying out HIV/AIDS education, although, they are 
trained to teach various school subjects. The reasons for this is that participatory approaches are child-centered and actively encourage pupils participation through playlets, drama, project work, songs, proverbs, story-telling, dance and debate. They should always cover the content of the subject because most of the school-based AIDS education failed due to incomplete implementation as a result of irregularity and unscheduled classes most especially in public schools.

ii. School children, most especially girls and orphans, should search for youth-friendly centre around to report cases of rape and abuse from the opposite sex or any of their teachers. This will prevent them from being infected with HIV because they will be given proper medication.

iii. Parents and guardians need to be well informed about teaching HIV/AIDS education to children as early as possible. This will prepare them for different types of negotiation they might come in contact with later in life. But more emphasis should be placed on abstinence for primary school pupils.

iv. Primary schools should begin HIV/AIDS education as early as possible and this should be continued throughout childhood and adolescence. This will alert them to their vulnerability to the disease before they reach the peak of vulnerable years.

v. Schools should try as much as possible to reduce school-related costs in public primary schools. This will enable the enrolment of the children of the poor, orphans and vulnerable children to increase and the government via the schools will be able to take care of all children irrespective of their tribe, family background, sex and religion.

vi. The government should monitor policies developed for successful implementation. Government should encourage good adult role models of sexual relationships by commending adults that have been good models in the society. The curricula planners should be encouraged to review the school syllabi in various HIV-carrier subjects in order to expand the content on HIV/AIDS transmission and prevention at all levels of education. The International Funding Agencies should sponsor more network proposals on HIV/AIDS based on primary schools.

\section{Acknowledgement}

The author would like to appreciate the UNDP for sponsoring the programme that led to this research work.

\section{References}

[1] Abakpa, B. O. \& Iji, C. O. (2011). Effect of Mastery Learning Approach on Senior Secondary Students' Achievement in Geometry. Journal of the Science Teachers' Association of Nigeria, 46 (1), 165-176.

[2] Abiam, P. O. \& Odok, J. K. (2006). Factors in Students' Achievement in Different Branches of Secondary School Mathematics. Journal of Education and Technology, 1 (1), 161168.

[3] Abiodun, O; Dairo, O. S \& Ojetunde, A. (2007). City Profile of HIV/AIDS in the city of Makurdi, Nigeria. Retrieved on 14/1/08 from www. Vuliabitat.org.

[4] Adimora, A. A. (2006). Poverty Fuels HIV among Black Heterosexuals. Journal of Acquired Immunodeficiency Syndromes.

[5] Agommuoh, P. C. \& Nzewi, U.M. (2003). Effects of Videotaped Instruction on Secondary School Students' Achievement in
Physics. Journal of the Science Teachers' Association of Nigeria 38 (1 \& 2), 88-93.

[6] Akinbote, R.O; Oduolowu, E.A; \& Lawal, B.O. (2001). Preprimary and Primary Education in Nigeria; A Basic Text. Ibadan. Stirling-Horden Publishers, Ibadan.

[7] Akinsola, M. K. \& Awofala, A.O.A. (2008): Effects of Problem Context and Reasoning Complexity on Mathematics Problem Solving Achievement and Transfer of Secondary School Students. European Journal of Scientific Research, 20 (3), 641-651.

[8] Akinsola, M. K. \& Awofala, A.O.A. (2009): Effects of Personalization of Instruction on Students' Achievement and Selfefficacy in Mathematics Word Problems. International Journal of Mathematical Education in Science and Technology, 40 (3), 389404.

[9] Arigbabu, A. A. \& Mji, A. (2004). Is gender a factor on mathematics performance among Nigerian preservice teachers? Sex Roles: A Journal of Research, 51 (II), 749-753.

[10] Awofala, A. O. A. \& Nneji, L. M. (2012). Effect of framing and Team Assisted Individualised Instructional Strategies on Students' Achievement in Mathematics. Journal of the Science Teachers Association of Nigeria, 43 (3), 20-28.

[11] Awofala, A. O. A. (2007). Women and the learning of mathematics. African Journal of Historical Sciences, 3 (1), 195213.

[12] Awofala, A. O. A. (2011 a). Effect of Concept Mapping Strategy on Students' Achievement in Junior Secondary School Mathematics. International Journal of Mathematics Trends and Technology, 2 (2), 11-16.

[13] Awofala, A. O. A. (2011 b). Is Gender a Factor in Mathematics Performance among Nigerian Senior Secondary Students with Varying School Organization and Location? International Journal of Mathematics Trends and Technology, 2 (3), 17-21.

[14] Awofala, A. O. A. Fatade, A. O., \& Ola-Oluwa, S. A. (2012). Achievement in Cooperative versus Individualistic GoalStructured Junior Secondary School Mathematics Classrooms in Nigeria, International Journal of Mathematics Trends and Technology, 3 (1), 7-12.

[15] Awofala, A. O. A., Arigbabu, A. A. \& Awofala, A. A. (2013). Effects of Framing and Team Assisted Individualised Instructional Strategies on Senior Secondary School Students' Attitudes toward Mathematics, Acta Didactica Napocensia, 6 (1), 1-22.

[16] Cohen, D. (2007). Poverty and HIV/AIDS in sub-Saharan Africa: Issues paper No. 27.

[17] Darwin, C. (1964). Teach Your Child About Sex.

[18] Fatade, A. O., Nneji, L. M., Awofala, A. O. A., \& Awofala, A. A. (2012). Mode of Entry and Gender as Determinants of Nigerian Pre-service Teachers' Performance in Degree Mathematics and Science Courses, International Journal of Mathematics Trends and Technology, 3 (3), 103-109.

[19] Freire, P. (1969). An Outline of Psycho analysis. New York; Norton.

[20] Freire, P. (1993). Pedagogy of the Oppressed. New York; Continuum.

[21] Kerlinger, F.N. (1973). Foundation of Behavioural Research. New York. Holt. Rinehand and Hinston.

[22] Kolawole, M.E.M. (2007). The Humanities and Paradign Shift: Revisiting our Relevance in the Age of Globalization and High Technology. A paper Presented at the First International Conference on Challenges and New Horizons in Education and Humanities at Babcock University. Ilisan Remo, Ogun State, July 10-13.

[23] Ogunleye, B. O. \& Babajide, V. F. T. (2011). Commitment to Science and Gender as determinants of Students' Achievement and Practical Skills in Physics. Journal of the Science Teachers' Association of Nigeria, 46 (1), 125-135.

[24] Ogunneye, W. (2003). Students' Understanding of the Concept of Gradient in Physics. A Case Study of Physics Students from Tai Solarin College of Education, Ijebu-Ode. Journal of the Science Teachers' Association of Nigeria, 38 (1 \& 2), 100-106.

[25] Ogunyemi, A. (1994). "Values Clarification Conventional Lecture Method, Pre-Service Teachers' Learning Outcomes in some Aspects of Population Education.” An unpublished Ph.D Thesis, University of Ibadan, Ibadan.

[26] Smith, R. (1989). Review of M. Blank and A. Marguis, Directing Discourse: 80 Situations for Teaching Meaningful Discourse for children). Child language Teaching and Therapy, Vol. 1 pp. 109110.

[27] UNAIDS/WHO (2007). AIDS Epidemic Update. 
[28] Wallerstein, N. (1983). Language and Culture of Conflict, Problem-posing in ESL Classroom Reading, M.A; AddisonWesley.

[29] World Bank, UNICEF and UNAIDS (2002). Education and HIV/AIDS. Ensuring Education Access for Orphans and Vulnerable Children. A Training Module. http://www.avet.org/worldstat.htm. Retrieved on 19/9/2013. http://www/vanguardngr.com/2013/08/hivaids Retrieved on 18/9/2013.

[30] Awofala, A. O. A, Balogun, T. A, \& Olagunju, M. A. (2011) Effects of three modes of personalization on students; achievement in mathematics word problems in Nigeria.
International Journal for Mathematics Teaching and Learning, Available at

http://www.cimt.plymouth.ac.uk/journal/awofala.pdf.

[31] Awofala, A. O. A. (2012) An Analysis of the new 9-year basic Education mathematics Curriculum in Nigeria. Acta Didactica Naponcensia, 5 (1), 18-28.

[32] South Africa Reflect Network (2010). What is Reflect? http://www.sareflect.org/index.php?option=com_content\&view=c ategory\&id $=38 \&$ layout $=$ blog\&Itemid $=55$.

[33] Awofala, A.O.A \& Sopekan, O. S. (2013). Recent Curriculum Reforms in Primary and Secondary Schools in Nigeria in the new Millennium, Journal of Education and Practice, 4 (5), 98-107. 